\title{
Application of scanning calorimetry to estimate soil organic matter loss after fires
}

\author{
Sergey V. Ushakov $\cdot$ Divya Nag $\cdot$ Alexandra Navrotsky
}

Received: 10 July 2010/Accepted: 7 September 2010/Published online: 21 September 2010

(C) The Author(s) 2010. This article is published with open access at Springerlink.com

\begin{abstract}
The severe heating of soil during wildfires and prescribed burns may result in adverse effects on soil fertility due to organic matter loss. No rapid and reliable procedure exists to evaluate soil organic matter (SOM) losses due to heating. Enthalpy of SOM combustion correlates with organic matter content. Quartz is a ubiquitous mineral in soils and has a remarkably constant composition and reversible $\alpha-\beta$ phase transition at $575^{\circ} \mathrm{C}$. We suggest that SOM content in heated and unheated soils can be compared using the ratio of SOM combustion enthalpy on heating to the $\beta-\alpha$ quartz transition enthalpy measured on cooling of the same sample. This eliminates the need to dry and weigh the samples, making possible field applications of the proposed method. The feasibility of using the $\left(\Delta H_{\text {comb som }}\right) /\left(\Delta H_{\beta-\alpha}\right.$ Qz) ratio was established with experiments on soil samples heated in the laboratory and the method was then used for evaluation of SOM loss on two pile burn sites at UC Berkeley's Blodgett Forest Research Station in Georgetown, California.
\end{abstract}

Keywords Soil · Fires · Organic carbon · Scanning calorimetry

\section{Introduction}

Organic matter content is a critical factor of soil quality and an important regulator of $\mathrm{CO}_{2}$ in the atmosphere. The dry combustion method of measuring soil organic carbon

S. V. Ushakov $(\bowtie) \cdot$ D. Nag · A. Navrotsky Peter A. Rock Thermochemistry Laboratory NEAT ORU, University of California at Davis, One Shields Ave, Davis, CA 95616, USA

e-mail: svushakov@ucdavis.edu
(SOC) concentration dates back to 1900 [1] and relies on quantitative analysis of $\mathrm{CO}_{2}$ evolved on combustion of soil organic matter. Today this procedure is considered the most accurate, but the high cost of modern dry combustion instruments is a limitation to many laboratories [2]. Acid pretreatment is often required for correction for inorganic carbon from carbonate minerals present in soil samples.

A wet chemical oxidation method (sometimes referred to as "wet combustion") was suggested in 1934 as a "procedure more rapid than others so far proposed useful for comparative purposes where no very exact determination is required" [3]. It has been used widely [4], however, it involves oxidation of soil carbon with chromic acid and is not feasible today due to the toxic wastes it generates. SOM content is often estimated as $k \cdot$ SOC, where $k$ is an empirical conversion factor which varies among soils and may reach values up to 2.0 [5]. Weight loss-on-ignition (LOI) is often used for "rapid and inexpensive" determination of SOM [6]. The recommended LOI procedure [4] includes overnight drying of the samples at $105^{\circ} \mathrm{C}$, weighing, combustion in a furnace, and final weighing. Due to chemisorbed and structural water, LOI values often exceed SOM content and soil-specific calibration is required to interpret them [2]. Concentration of soil organic matter is not uniform and depends not only on the soil type and usage but also on site-specific landscape characteristics [2].

There is an increasing need for robust and rapid quantitative measurements of fire's effect on soils [7]. Fires can produce soil temperatures in excess of $300{ }^{\circ} \mathrm{C}$ in the case of wild forest fires and in excess of $800{ }^{\circ} \mathrm{C}$ for log pile fires [8]. Calorimetric methods have been used previously to characterize biomass $[9,10]$ and measure combustion enthalpies and ignition temperatures [11-14]. Here, we propose a rapid and reliable calorimetric method to estimate SOM loss from soils based on the ratio of SOM 
combustion enthalpy on heating the sample in air to the enthalpy of the $\beta-\alpha$ phase transition in quartz on cooling the same sample. Quartz $\left(\mathrm{Qz}, \mathrm{SiO}_{2}\right)$ is the most commonly found mineral on the Earth's surface and is ubiquitously present in soils $[16,17]$. On heating at ambient pressure above $575{ }^{\circ} \mathrm{C}$, quartz reversibly transforms to a high temperature phase [18]. Decrease of this ratio $\left(\Delta H_{\text {comb som }}\right) /$ $\left(\Delta H_{\beta-\alpha} \mathrm{Qz}\right)$ in heated soil compared with unheated samples indicates SOM loss. The method has potential to be employed in the field since it does not require sample weighing or drying.

\section{Materials and methods}

The proposed method was developed using a soil sample (denoted as Yolo) in which SOM loss was induced by controlled heating in the laboratory and analyzed using thermogravimetry (TG) and differential scanning calorimetry (DSC). Based on these experiments, a thermal analysis procedure to estimate SOM loss using ( $\left.\Delta H_{\text {comb soM }}\right) /$ $\left(\Delta H_{\beta-\alpha}\right.$ Qz) was developed and tested on samples from two pile burn sites at the UC Berkeley Blodgett Research Forest Station in Georgetown, CA.

Sample Yolo was collected near the University of California Davis campus. The sample core $\sim 200 \mathrm{~g}$ in weight was collected from the surface to $10 \mathrm{~cm}$ depth. The details on characterization of this sample were reported earlier [15]. The sample was dried in a vacuum oven at $50{ }^{\circ} \mathrm{C}$ for $30 \mathrm{~h}$, ground and homogenized. Portions of sample were heated in air at $300{ }^{\circ} \mathrm{C}$ for different time intervals to cause partial loss of SOM.

A Netzsch 409 thermal analyzer was used for controlled heating of Yolo sample and for TG and DSC measurements on all soils. The samples $10-70 \mathrm{mg}$ in mass were heated to $800{ }^{\circ} \mathrm{C}$ followed by cooling to $300{ }^{\circ} \mathrm{C}$. All experiments were performed in static air in platinum crucibles at $20{ }^{\circ} \mathrm{C} \mathrm{min}^{-1}$. Sensitivity calibration was performed with sapphire standard. Temperature calibration was performed by melting metal standards. Instrument software was used to determine weight loss and combustion enthalpies of soil samples.

The thermal analysis procedure developed on Yolo sample was tested on soil cores collected from a pile burn. A widely used fuel management technique in California, aimed at reducing the possibility of forest fires and managing biomass, is the collection of fallen or cut trees/shrubs to burn in the winter when there is little danger of starting uncontrolled fires. This fire prevention method is often referred to as pile burns. Samples were collected from pile burns conducted at UC Berkeley's Blodgett Forest Research Station, Georgetown, CA, 4 months after the burn. The location has Holland and Holland-Musick soil types. Holland samples were collected from compartment
321 and Holland-Musick samples were collected from compartment 481 [15]. Samples of Holland soil were collected from depths of $0-2.5$ and $2.5-5 \mathrm{~cm}$ (Table 2). During collection, we did not expect the effect of the pile burns on SOM content to be so drastic and did not collect samples below $5 \mathrm{~cm}$ at the Holland site. However, a soil core was collected on the Holland-Musick site, which allowed analyses of samples from depths 5-7.5 and $7.5-10 \mathrm{~cm}$. Samples of unburned soil were collected from 0 to $2.5 \mathrm{~cm}$ depth near the burn sites.

\section{Results and discussion}

SOM loss evaluation on controlled heating of Yolo sample

Heating of the dried sample from 200 to $800{ }^{\circ} \mathrm{C}$ in air in the TG/DSC produced weight loss $\sim 13 \mathrm{wt} \%$ and a wide exothermic peak. Assigning heat effect and weight loss to SOM oxidation and removal as $\mathrm{CO}_{2}$ and water, the SOM combustion enthalpy in the dried Yolo sample is calculated to be $17.1 \mathrm{~kJ} / \mathrm{g}$. In addition to the exothermic peak at $300-600{ }^{\circ} \mathrm{C}$ related to SOM combustion, all samples show an endothermic dip around $570{ }^{\circ} \mathrm{C}$ where the $\alpha-\beta$ quartz phase transition occurs. This transition is reversible and much more pronounced on cooling when all organic matter has been burned out.

Table 1 and Fig. 1 summarize the results of TG/DSC analysis on the Yolo sample, after drying at $50{ }^{\circ} \mathrm{C}$ for $30 \mathrm{~h}$ and after holding at $300{ }^{\circ} \mathrm{C}$ for 10,30 , and $60 \mathrm{~min}$. During the data analysis, we assumed that all organic matter was removed from the sample after heating to $800{ }^{\circ} \mathrm{C}$. We also neglected weight changes/heat effects due to possible oxidation/reduction of inorganic compounds including elements with variable valence state such as $\mathrm{Fe}$ and $\mathrm{Mn}$. There were no additional DSC peaks attributed to such reactions.

The enthalpy of combustion per gram of organic matter decreased by $20 \%$ when the holding time at $300{ }^{\circ} \mathrm{C}$ was increased from 10 to $60 \mathrm{~min}$. An increase in combustion onset temperature was also observed: from $301{ }^{\circ} \mathrm{C}$ in the sample annealed for $10 \mathrm{~min}$ to $376^{\circ} \mathrm{C}$ for the sample annealed for $60 \mathrm{~min}$. SOM loss in the Yolo sample heated at $300{ }^{\circ} \mathrm{C}$ was calculated from weight loss and combustion enthalpy per gram of sample compared to those in unburned sample (Table 1). Because of the decrease of combustion enthalpy per gram of SOM with increase of exposure time, we would expect that SOM loss from combustion enthalpy data would be overestimated. Indeed, heating of Yolo sample for $60 \mathrm{~min}$ at $300{ }^{\circ} \mathrm{C}$ results in $56 \mathrm{wt} \%$ SOM loss from TG data and $70 \mathrm{wt} \%$ loss from DSC data. 
Table 1 Thermal analysis results and soil organic matter loss calculations for Yolo sample after drying at $50{ }^{\circ} \mathrm{C}$ and controlled heating

\begin{tabular}{|c|c|c|c|c|c|c|c|c|c|c|c|c|}
\hline \multirow[t]{2}{*}{$T /{ }^{\circ} \mathrm{C}$} & \multirow[t]{2}{*}{ Time } & \multicolumn{5}{|c|}{ TG/DSC analysis $25-800-25^{\circ} \mathrm{C}^{\mathrm{a}}$} & \multirow[t]{2}{*}{$-\Delta H_{\mathrm{c}} / m \mathrm{~kJ} / \mathrm{g}$} & \multirow[t]{2}{*}{$-\Delta H_{\mathrm{c}} / \Delta m / \mathrm{kJ} / \mathrm{g} \mathrm{SOM}$} & \multirow[t]{2}{*}{$\Delta H_{\mathrm{c}} \Delta / H_{\mathrm{qz}}$} & \multicolumn{3}{|c|}{ SOM loss $/ w_{t} \%^{b}$} \\
\hline & & $m / m g$ & $\Delta m / \mathrm{wt} \%$ & $-\Delta H_{\mathrm{c}} / \mathrm{J}$ & $T_{\mathrm{c}} /{ }^{\circ} \mathrm{C}$ & $-\Delta H_{\mathrm{qz}} / \mathrm{J}$ & & & & TG & $-\Delta H_{\mathrm{c}} / m$ & $\Delta H_{\mathrm{c}} / \Delta H_{\mathrm{qz}}$ \\
\hline 50 & $30 \mathrm{~h}$ & 17.14 & 13.4 & 39.33 & 264 & 0.0423 & 2.3 & 17.1 & 930 & 0 & 0 & 0 \\
\hline 300 & $10 \mathrm{~m}$ & 25.56 & 8.6 & 31.30 & 301 & 0.0626 & 1.2 & 14.2 & 500 & 36 & 47 & 46 \\
\hline 300 & $30 \mathrm{~m}$ & 24.96 & 7.2 & 24.00 & 319 & 0.0633 & 1.0 & 13.3 & 379 & 46 & 58 & 59 \\
\hline 300 & $60 \mathrm{~m}$ & 29.12 & 5.8 & 20.20 & 376 & 0.0629 & 0.7 & 11.9 & 321 & 56 & 70 & 65 \\
\hline
\end{tabular}

All samples were heated to $800{ }^{\circ} \mathrm{C}$ in static air at $20^{\circ} \mathrm{C} / \mathrm{min}$

${ }^{\text {a }} m$ is the mass of analyzed sample after drying or annealing; $\Delta m$ is change in mass of sample on heating from 200 to $800{ }^{\circ} \mathrm{C} ; \Delta H_{\mathrm{c}}$ is total enthalpy of combustion obtained by integration of exothermic peak; $T_{\mathrm{c}}$ is onset of combustion (ignition temperature) found by exothermic peak; $\Delta H_{\mathrm{qz}}$ is enthalpy of $\beta-\alpha$ transition of quartz, measured on cooling segment

b SOM loss calculated as $100 \times(x$ dried $-x$ heated $) /(x$ dried $)$, were $(x$ dried $)$ and ( $x$ heated $)$ are either $\Delta m(\%)$ from TG, combustion enthalpy per gram of sample $\left(\Delta H_{\mathrm{c}} \mathrm{m}^{-1}\right)$, or $\Delta H_{\mathrm{c}} / \Delta H_{\mathrm{qz}}$ ratio

Fig. 1 Thermal analysis of Yolo sample in air at $20^{\circ} \mathrm{C} / \mathrm{min}$. Top TG traces on heating, Bottom DSC traces on heating. Inset DSC traces showing $\beta-\alpha$ quartz phase transition on cooling. Heat treatment prior analysis is labeled next to trace
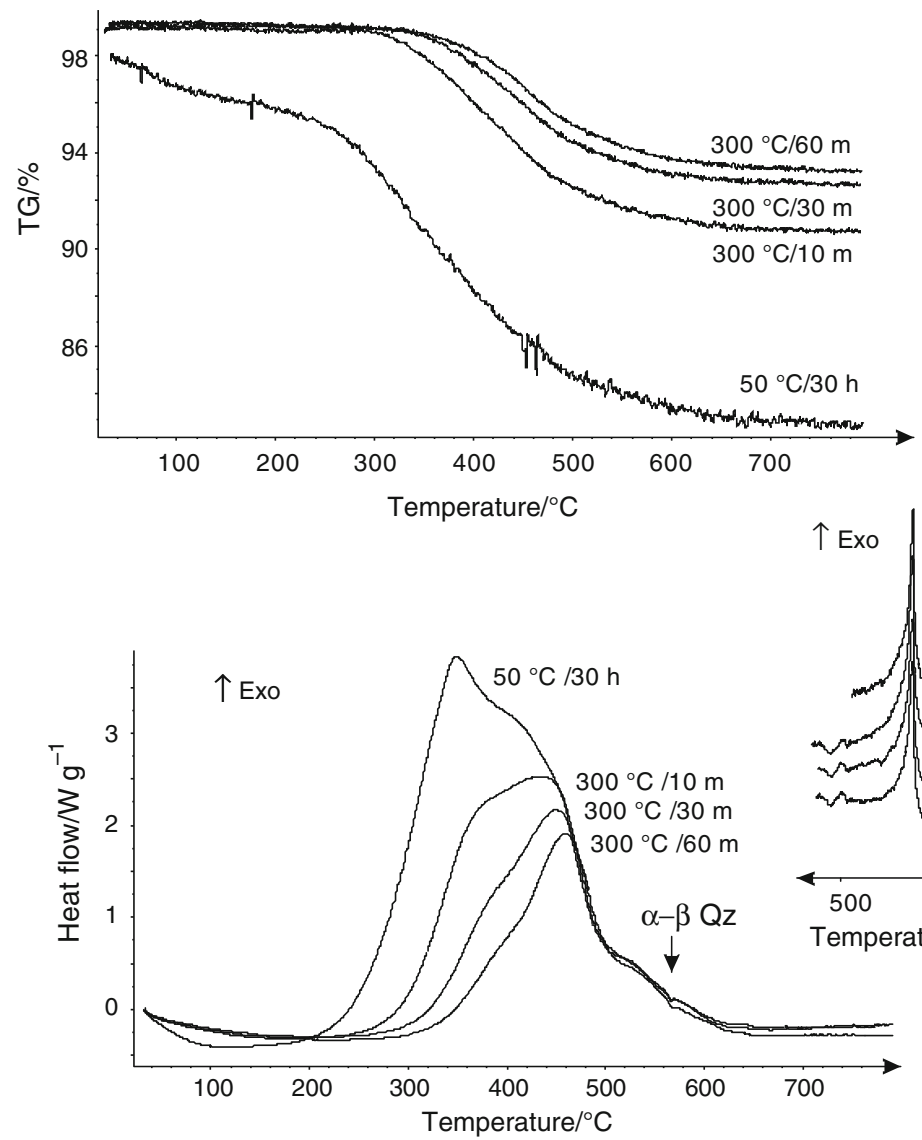

No need to weigh: $\Delta H_{\mathrm{c}} / \Delta H_{\mathrm{qz}}$ ratio

Due to the very small content of impurities in natural quartz [16], the enthalpy of the $\alpha$ to $\beta$ transition $(8.3 \mathrm{~J} / \mathrm{g}$ [18]) does not vary with soil type and the observed enthalpy can be used to evaluate quartz content in any soil sample [15]. The measurement of enthalpy of transition of quartz in soils is best accomplished from the exothermic DSC peak on cooling corresponding to $\Delta H_{\beta-\alpha}$ transition, since on heating $\alpha$ to $\beta$ transition is masked by large exothermic peak from SOM combustion (Figs. 1, 3). No other minerals commonly found in soils exhibit reversible transitions, thus cooling traces are often not recorded on thermal analysis of soils [19].

The change in combustion enthalpy of the organic matter may be revealed using the quartz transition as an internal standard, eliminating the need to dry and weigh the samples. A decrease in the ratio of combustion enthalpy of 
organic matter to enthalpy of phase transition of quartz present in the soil $\left(\Delta H_{\text {comb som }}\right) /\left(\Delta H_{\alpha-\beta} \mathrm{Qz}\right)$ (denoted further as $\left.\Delta H_{\mathrm{c}} / \Delta H_{\mathrm{qz}}\right)$ indicates organic matter loss. $\Delta H_{\mathrm{c}}$ is the integrated area of the exothermic peak on heating from 200 to $600{ }^{\circ} \mathrm{C}$ and $\Delta H_{\mathrm{qz}}$ is the integrated area of the exothermic peak on cooling due to the $\beta-\alpha$ transition in quartz. As one can see from Table 1 and Fig. 2, SOM loss calculated from $\Delta H_{\mathrm{c}} / \Delta H_{\mathrm{qz}}$ ratio is similar to that calculated from combustion enthalpy per gram of sample $\left(\Delta H_{\mathrm{c}} \mathrm{m}^{-1}\right)$,
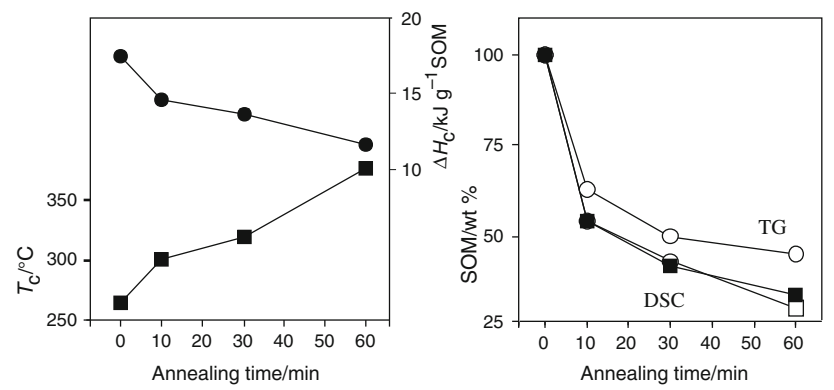

Fig. 2 Left: Change in combustion onset and enthalpy of combustion per gram of soil organic matter of Yolo sample as a function of annealing time at $300{ }^{\circ} \mathrm{C}$. Right: Soil organic matter loss in the samples calculated from mass loss on heating (TG), from decrease in combustion enthalpy per gram of the sample (DSC open squares) and from $\Delta H_{\mathrm{c}} / \Delta H_{\mathrm{qz}}$ ratio (DSC solid squares). The values for zero annealing time correspond to unheated samples the largest difference being $7 \%$ for the sample annealed at $300{ }^{\circ} \mathrm{C}$ for $60 \mathrm{~min}$.

Scanning calorimetry of soil samples from pile burn sites

A test of the application of the $\Delta H_{\mathrm{c}} / \Delta H_{\mathrm{qz}}$ ratio for estimation of SOM loss was performed on samples collected from the pile burns. No sieving or drying was performed before the analysis and soil samples were loaded field moist after removal visible leaves and roots and stones. The resulting DSC traces for Holland-Musick samples are plotted in Fig. 3 and SOM losses calculated from $\Delta H_{\mathrm{c}} / \Delta H_{\mathrm{qz}}$ ratios are presented in Table 2.

Endothermic peaks at $25-200{ }^{\circ} \mathrm{C}$ related to water loss are observed for all samples. It is not surprising since both sites were exposed to rain and then buried under snow for 4 months after burning. An unburned sample indicates higher water content than burned samples above $5 \mathrm{~cm}$ depth (Fig. 3). This correlates with organic matter loss in the burned samples since SOM is the most hygroscopic constituent in the soil and can hold up to 20 times its weight in water [20].

From the $\Delta H_{\mathrm{c}} / \Delta H_{\mathrm{qz}}$ ratio, more than $90 \mathrm{wt} \%$ of $\mathrm{SOM}$ was lost in the first $5 \mathrm{~cm}$ of soil at both sites. Substantial loss of organic matter is evident for the Holland-Musick sample at 5-7.5 cm depth. For the sample from 7.5-10 cm
Fig. 3 Differential scanning calorimetry traces of HollandMusick soil type samples on heating in air at $20^{\circ} \mathrm{C} / \mathrm{min}$. Traces for $\beta-\alpha$ quartz phase transition on cooling are shown on the inset. Control soil sample collected outside of pile burn is selected by a thicker trace

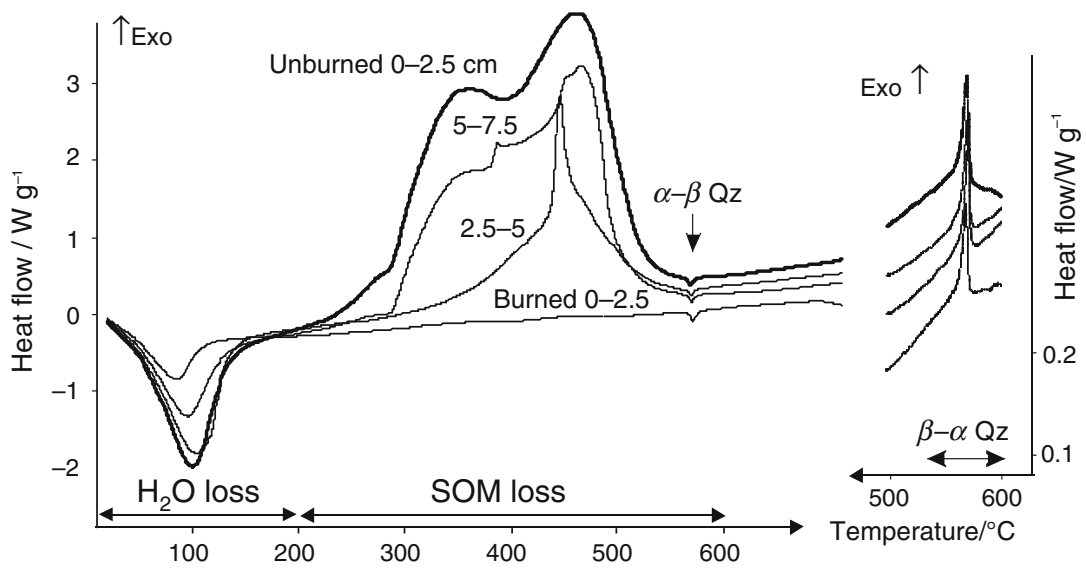

Table 2 Thermal analysis of samples from two pile burns site in Blodgett Forest Research Station

\begin{tabular}{|c|c|c|c|c|c|c|}
\hline Soil type & Depth/cm & $-\Delta H_{\mathrm{c}} / \mathrm{mJ}$ & $T_{\mathrm{c}} /{ }^{\circ} \mathrm{C}$ & $-\Delta H_{\mathrm{q} z} / \mathrm{mJ}$ & $\Delta H_{\mathrm{c}} / \Delta H_{\mathrm{qz}}$ & SOM loss/wt $\%$ \\
\hline \multirow[t]{3}{*}{ Holland } & Unburned $0-2.5$ & 47094 & 299 & 128.8 & 366 & 0 \\
\hline & Burned 0-2.5 & 814 & - & 195.3 & 4.2 & 98.9 \\
\hline & $2.5-5$ & 879 & - & 232.5 & 3.8 & 99 \\
\hline \multirow[t]{5}{*}{ Holland-Musick } & Unburned $0-2.5$ & 44900 & 287 & 74.94 & 599 & 0 \\
\hline & Burned 0-2.5 & 9.17 & 414 & 171.5 & 0.1 & 100 \\
\hline & $2.5-5$ & 564.1 & 408 & 85.76 & 6.6 & 98.9 \\
\hline & $5-7.5$ & 16822 & 367 & 79.18 & 212 & 64.6 \\
\hline & $7.5-10$ & 55799 & 289 & 117 & 477 & 20.4 \\
\hline
\end{tabular}


depth, the $\Delta H_{\mathrm{c}} / \Delta H_{\mathrm{qz}}$ ratio is only $20 \%$ lower than for the unburned control sample from 0 to $2.5 \mathrm{~cm}$ depth. This variation may be due to decrease in SOM content with depth.

Total organic matter loss on heating is a function of heat input, exposure time, moisture content, and aeration. $\Delta H_{\mathrm{c}} / \Delta H_{\mathrm{qz}}$ can only be used as an integral indicator and cannot be distinguished among these factors. It is likely that changes in combustion onset and enthalpy per gram of organic matter can provide possibilities to reconstruct time-temperature profiles during fires, but this will require site-specific calibrations.

We want to emphasize that while knowing accurate sample mass is paramount for TG measurements and prolonged drying or measuring water content is needed for data on combustion enthalpy per gram of the sample to be meaningful, weight is not needed for calculation of the ratio $\Delta H_{\mathrm{c}} / \Delta H_{\mathrm{qz}}$. The limitation of using wt $\%$ loss from TG method or combustion enthalpy per gram of sample from DSC is that the difference in water content between burned and unburned samples will affect the results. Therefore, one would have to dry the sample first which is not practical in the field. The proposed $\Delta H_{\mathrm{c}} / \Delta H_{\mathrm{qz}}$ approach circumvents this difficulty and should be easy and fast to apply in the field if a robust portable DSC is available. Such a field application would require minimum sample preparation and portability, so one could perform the test in the field whenever a go/no-go decision needs to be made after a test burn in a prescribed burn scenario. We propose that an inexpensive field version of a scanning calorimeter operating from room temperature to $600{ }^{\circ} \mathrm{C}$ can be constructed and applied for field analysis of soil heated during wild and prescribed fires. The experiments can be conducted in static air with crucible-free loading, utilizing the ratio of peak areas related to combustion (on heating) to quartz phase transition (on cooling) to automate data collection and analysis. A Tian-Calvet [21] type calorimeter with four cells open from both ends would easily provide robustness and air circulation needed for such experiments but a conventional DSC could also be employed. In addition to proposed application for evaluation of organic matter loss after fires, DSC traces can also be used to evaluate differences in water and organic matter contents and composition between soil types and to establish sitespecific sampling strategies.

\section{Conclusions}

Scanning calorimetry can be used to estimate soil organic matter loss after fires. This study indicated that the quartz present in the soils could be used as an internal standard and the $\left(\Delta H_{\text {comb som }}\right) /\left(\Delta H_{\beta-\alpha}\right.$ Qz) ratio as an indicator of organic matter loss. This method eliminates the need for weighing and drying the sample and could be used in the field.

Acknowledgements This research was partially funded by NSF grant EAR0634137. Divya Nag was a volunteer high school student. Sample collection in UC Berkeley Blodgett Forest Research Station was performed under proposal BF08-01SU. We thank Professor Scott Stephens and Dr. Robert York, UC Berkeley Center for Forestry, for help with collection of the samples from pile burn sites in Blodgett Forest Research Station and James Hughes for his comments on the manuscript.

Open Access This article is distributed under the terms of the Creative Commons Attribution Noncommercial License which permits any noncommercial use, distribution, and reproduction in any medium, provided the original author(s) and source are credited.

\section{References}

1. Dennstedt M. Soda-lime apparatus for elementary analysis and carbon dioxide estimation. Chemiker-Zeitung. 1908;32:77.

2. Konen ME, Jacobs PM, Burras CL, Talaga BJ, Mason JA. Equations for predicting soil organic carbon using loss-on-ignition for north central U.S. soils. Soil Sci Soc Am J. 2002;66(6): 1878-81.

3. Walkley A, Black JA. An examination of the Degtjoreff method for determining soil organic matter, and a proposed modification of the chromic acid titration method. Soil Sci. 1934;37:29-38.

4. Schulte EE, Hopkins BG. Estimation of soil organic matter by weight loss-on-ignition. SSSA Special Publ. 1996;46:21-31.

5. Nelson DW, Sommers LE. Total carbon, organic carbon and organic matter. In: Sparks DL, editor. Methods of soil analysis. Part 3, chemical methods, no. 5. Soil science society of America book series, vol 5. Madison, WI: SSSA; 1996.

6. Ping JL, Dobermann A. Variation in the precision of soil organic carbon maps due to different laboratory and spatial prediction methods. Soil Sci. 2006;171(5):374-87.

7. Neil McKenzie DJ, Isbell R, Brown K. Australian soils and landscapes. 1st ed. Collingwood: CSIRO; 2004.

8. Walker J, Raison RJ, Khanna PK. Fire. In: Russell JS, Isbell RF, editors. Australian soils: the human impact. St. Lucia, Queensland, Australia; Manchester, NH, USA: University of Queensland Press; 1986. p. 185-216.

9. Nunez-Regueira L, Rodriguez-Anon J, Proupin J, Vilanova Diz A. Calorimetry as a tool to design campaigns to prevent and fight forest fires originating from shrub species. Thermochimica Acta. 2002;394(1-2):279-89.

10. Nunez-Regueira L, Rodriguez-Anon JA, Proupin J, Mourino B, Artiaga-Diaz R. Energetic study of residual forest biomass using calorimetry and thermal analysis. J Therm Anal Calorim. 2005;80(2):457-64.

11. Salgado J, Gonzalez MI, Armada J, Paz-Andrade MI, Carballas M, Carballas T. Loss of organic matter in Atlantic forest soils due to wildfires. Calculation of the ignition temperature. Thermochimica Acta. 1995;259(1):165-75.

12. Salgado J, Mato MM, Vazquez-Galinanes A, Paz-Andrade MI, Carballas T. Comparison of two calorimetric methods to determine the loss of organic matter in galician soils (nw Spain) due to forest wildfires. Thermochimica Acta. 2004;410(1-2):141-8.

13. Barros N, Salgado J, Feijoo S. Calorimetry and soil. Thermochim Acta. 2007;458(1-2):11-7. 
14. Salgado J, Proupin J, Villanueva M, Rodriguez-Anon JA, Barros $\mathrm{N}$. Effect of the soil uses on their thermal stability. J Therm Anal Calorim. 2010;99(3):911-6.

15. Ushakov SV, Nag D, Navrotsky A. Does dirt burn? Application of scanning calorimetry to estimate soil organic matter loss after fires. In: Proceedings of the NATAS annual conference on thermal analysis and applications. 2008. p. 36/1-36/11.

16. Dixon JB, Schulze DG. Soil Science Society of A. Soil mineralogy with environmental applications. Soil science society of America book series, no. 7. Madison, Wisconsin, USA: Soil Science Society of America; 2002.
17. Singer A. Quartz synthesis by soxhlet leaching of basaltic rock. Soil Sci. 1990;150(3):630-6.

18. Bale CW, Pelton AD, Thompson WT, Eriksson G, Hack K, Chartrand P, Decterov S, Melancon J, Petersen S. Factsage: the integrated thermodynamic databank system, Thermfact. 2008. www.factsage.com.

19. Dixon JB, Weed SB, Dinauer RC. Minerals in soil environments. Madison, Wisconsin: Soil Science Society of America; 1977.

20. Tate RL. Soil organic matter: biological and ecological effects. New York: Wiley; 1987.

21. Calvet EJP. Calorimeter. United States. 1962. 